\title{
NILAI INDEKS GLIKEMIK BERBAGAI PRODUK OLAHAN SUKUN (Artocarpus altilis)
}

\author{
(Glycemic Index Value of Breadfruit (Artocarpus altilis) Products) \\ Rakhmawati FKR ${ }^{1}$, Rimbawan ${ }^{1}$, dan Leily Amalia ${ }^{1 *}$ \\ 1 Departemen Gizi Masyarakat, Fakultas Ekologi Manusia, Institut Pertanian Bogor, Bogor 16680. \\ * Alamat korespondensi: Departemen Gizi Masyarakat, Fakultas Ekologi Manusia, Institut Pertanian \\ Bogor, Bogor 16680. Telp: 0251-8621258; Fax: 0251-8622276; Email: leilyamalia@yahoo.com
}

\begin{abstract}
A new approach based on glycemic index was suggested in choosing foods as a source of carbohydrate. A study on glycemic index of selected Indonesian food has been conducted such as breadfruit which is a source of carbohydrate. The objective of this study was to analyze glycemic index value of breadfruit products such as fried breadfruit, steamed breadfruit, boiled breadfruit, and breadfruit cookies. These processing was choosen based on common method of breadfruit cooking in Indonesia. Breadfruits from Kudus were selected. That breadfruit had processed into four kinds of breadfruit products namely fried breadfruit, steamed breadfruit, boiled breadfruit, and breadfruit cookies. The foods were analyzed the nutrient composition of the four breadfruit products. Six healthy subjects (3 males and 3 females) with BMI between 18.5 and $22.9 \mathrm{~kg} / \mathrm{m}^{2}$ were selected. GI value of four breadfruit products determined by standard method (Miller 1996). Measurement of GI was conducted after approval of the Ethics Committee (No. LB.03.04/KE/4914/2010) received. Proximate analysis showed that nutrient contents of the products were as follows : moisture content (wet based, wb) of breadfruit products such as fried breadfruit, steamed breadfruit, boiled breadfruit, and breadfruit cookies were $51.01 \%, 71.75 \%, 79.91 \%$, and $4.24 \%$ respectively, protein content (dry based, $d b$ ) were $1.22 \%, 2.11 \%, 3.2 \%$, and $3.53 \%$ respectively, fat content $(d b)$ were $20.07 \%, 0.61 \%, 0.73$, and $30.12 \%$ respectively, carbohydrate by difference content ( $d b)$ were $73.36 \%, 90.30 \%, 90.78 \%$, and $64.37 \%$ respectively, and total dietary fiber content $(d b)$ were $16.5 \%, 25.76 \%, 30.47 \%$, and $4.36 \%$ respectively. The result showed that glycemic index of fried breadfruit, steamed breadfruit, boiled breadfruit, and breadfruit cookies were 82, 89, 85, and 80 respectively. Those four products were classified as high Gl category. Statistical analysis showed that treatment did not affect the $G I$ value.
\end{abstract}

Key words: glycemic index, steamed breadfruit, boiled breadfruit, breadfruit cookies

\section{PENDAHULUAN}

Pengetahuan mengenai pangan dan gizi semakin diperlukan seiring dengan berkembangnya paradigma sehat, seperti diet, pengaturan pola hidup, maupun aktivitas fisik. Salah satu pendekatan yang saat ini berkembang dan terkait dengan pengaturan pola makan terutama untuk mencegah obesitas dan penyakit Diabetes Mellitus adalah konsep Indeks Glikemik (IG). Menurut Rimbawan dan Siagian (2004), konsep ini menekankan pada pentingnya mengenal pangan (karbohidrat) berdasarkan kecepatan naiknya kadar glukosa darah setelah pangan tersebut dikonsumsi. Konsep Indeks Glikemik memang disusun untuk semua orang, antara lain orang yang mengalami obesitas, diabetesi, atlet, bahkan orang sehat sekalipun. Informasi nilai indeks glikemik suatu bahan pangan sangat bermanfaat untuk memilih pa- ngan, terutama pangan sumber karbohidrat, di antaranya sukun.

Sukun merupakan salah satu tanaman pangan sumber karbohidrat selain beras yang masih belum dimanfaatkan secara optimal. Menurut Koswara (2006), sukun dapat dijadikan sebagai pangan alternatif karena keberadaannya tidak seiring dengan pangan sumber karbohidrat yang biasa dikonsumsi masyarakat Indonesia, yaitu beras. Dengan demikian keberadaan sukun dapat menutupi kekosongan beras saat tidak dalam periode produksi. Sukun dapat dipakai sebagai pangan alternatif pada bulan-bulan Januari, Februari dan September, di mana pada bulan-bulan tersebut biasanya merupakan masa paceklik padi. Musim panen sukun dua kali setahun, yaitu panen raya bulan Januari - Februari dan panen susulan pada bulan Juli - Agustus. 
Produksi sukun di Indonesia terus meningkat dari 35.435 ton pada tahun 2000 menjadi 92.014 ton pada tahun 2007 dengan luas panen 13.359 ha. Wilayah yang merupakan sentra produksi sukun saat ini adalah Jawa Barat, Jawa Tengah, Jawa Timur, DI Yogyakarta, Kalimantan Timur, NTT, Sumatera Selatan, Lampung, Sulawesi Selatan dan Jambi (Direktorat Jenderal Hortikultura, 2007). Berdasarkan data produksi tersebut, sukun memiliki potensi untuk dijadikan sumber pangan alternatif pengganti nasi (Saptoning, 2010).

Beberapa penelitian mengenai indeks glikemik pangan lokal khususnya buah yang dapat dijadikan sumber karbohidrat masih sangat terbatas. Sukun merupakan salah satu produk pangan lokal yang keberadaanya cukup potensial sehingga diperlukan informasi nilai indeks glikemik berbagai produk olahan sukun (Artocarpus altilis), seperti sukun goreng, sukun rebus, sukun kukus, maupun kukis sukun.

Tujuan umum penelitian ini untuk mengetahui nilai indeks glikemik berbagai produk olahan sukun (Artocarpus altilis). Tujuan khusus penelitian ini, antara lain: (1) Mengkaji komposisi zat gizi yang terkandung pada sukun goreng, sukun kukus, sukun rebus, dan kukis sukun; (2) Mengkaji derajat gelatinisasi sukun goreng, sukun kukus, sukun rebus, dan kukis sukun, dan (3) Mengkaji nilai indeks glikemik sukun goreng, sukun kukus, sukun rebus, dan kukis sukun

\section{METODE}

\section{Waktu dan Lokasi Penelitian}

Penelitian ini dilaksanakan pada bulan Juli hingga September 2010. Penelitian dilakukan di beberapa laboratorium di lingkungan Departemen Gizi Masyarakat, Fakultas Ekologi Manusia, Institut Pertanian Bogor, yaitu Laboratorium Percobaan Pangan yang digunakan untuk memperoleh standar pengolahan produk sukun, Laboratorium Kimia dan Analisis Makanan yang digunakan untuk menganalisis zat gizi produk olahan sukun, serta Teaching Cafetaria yang digunakan untuk mengukur respon glukosa darah subyek penelitian.

\section{Bahan dan Alat}

Bahan yang digunakan pada proses pengolahan sukun menjadi produk olahan sukun antara lain: bawang putih, garam, tepung terigu, tepung sukun, mentega, susu skim, kuning telur, gula tepung, dan baking powder. Bahan kimia yang digunakan untuk uji proksimat produk olahan sukun adalah air destilanta atau aquades, selenium mix, $\mathrm{HCl}(0.03 \mathrm{~N} ; 0.1 \mathrm{M}$ dan $6 \mathrm{M}), \mathrm{NaOH} 30 \%$, asam borat $\left(\mathrm{H}_{3} \mathrm{BO}_{3} 3 \%\right)$, etanol 95\%, aseton, buffer fosfat asam nitrat $\left(\mathrm{HNO}_{3}\right)$, asam sulfat $\left(\mathrm{H}_{2} \mathrm{SO}_{4}\right)$, pepsin, natrium bikarbonat $\left(\mathrm{NaHCO}_{3}\right)$, hexan dan sodium asetat. Bahan yang digunakan untuk uji derajat gelatinisasi adalah $\mathrm{NaOH} 10 \mathrm{M}, \mathrm{HCl} 0.5 \mathrm{M}$, larutan iod $0.1 \mathrm{~N}$, dan air destilata atau aquades.

Peralatan yang digunakan pada proses pengolahan sukun menjadi produk olahan, antara lain timbangan digital, kompor, baskom, piring, gelas ukur, panci, panci kukus, penggorengan, saringan, ayakan tepung, cetakan, loyang, oven, pisau, dan mangkuk. Alat yang digunakan untuk uji proksimat antara lain adalah cawan alumunium, cawan porselen, desikator, oven, timbangan analitik, sudip, tanur, labu lemak, labu kjedahl, alat destruksi, alat destilasi, erlenmeyer, labu semprot, corong, pompa vakum, kertas saring Whatman 40, pipet volumetrik, dan soxhlet. Alat yang digunakan untuk uji derajat gelatinisasi antara lain timbangan analitik, blender, pipet, sentrifus, tabung reaksi, pipet volumetrik, dan spektrofotometer optima SP-300. Adapun peralatan yang digunakan untuk mengukur kadar glukosa darah adalah glukometer One Touch Glucose Blood System.

\section{Pemilihan Sampel dan Persiapan}

Sampel sukun yang digunakan dalam penelitian ini adalah sukun (Artocarpus altilis) yang berasal dari perkebunan rakyat sukun $\mathrm{Ge}$ bog di Kudus, Jawa Tengah. Sukun dipilih yang memiliki umur panen 2.5-3 bulan (agak matang), kulit buah berwarna hijau kekuningan, serta kulit mulai mengeluarkan getah berupa noda-noda putih yang agak mengkilap.

\section{Pengolahan Sukun}

Pembuatan sukun goreng dilakukan dengan menggoreng sukun yang telah dilumuri bumbu (bawang putih dan garam) selama 8 menit. Proses pembuatan sukun kukus dilakukan dengan cara mengukus sukun selama 20 menit. Sukun rebus dihasilkan dari proses perebusan sukun dengan air selama 15 menit. Kukis sukun pada penelitian ini diperoleh berdasarkan penelitian Wincy (2001), yaitu membuat tepung sukun terlebih dahulu, kemudian dilakukan pembuatan kukis sukun (tepung sukun, tepung terigu, gula tepung, margarin, soda kue, kuning telur, garam, dan susu skim) 
yang dipanggang pada suhu $160^{\circ} \mathrm{C}$ selama 5 menit kemudian suhunya diturunkan menjadi $150^{\circ} \mathrm{C}$ selama 15 menit.

\section{Analisis Zat Gizi Sukun Goreng, Sukun Kukus,} Sukun Rebus, dan Kukis Sukun

Analisis komposisi zat gizi ini meliputi uji proksimat, yaitu analisis kadar air (Metode Oven Biasa), lemak (Metode Ekstraksi Soxhlet), protein (Metode Kjeldahl), abu (metode kering), dan karbohidrat by difference), analisis total serat makanan (metode enzimatik), dan pengukuran tingkat gelatinisasi (IRRI, 1978).

\section{Pemilihan Subyek}

Pemilihan subjek penelitian dilakukan secara purposif karena alasan kemudahan dalam penelitian, yaitu 6 orang mahasiswa Institut Pertanian Bogor, yaitu terdiri atas 3 orang perempuan dan 3 orang laki-laki, bersedia mengikuti penelitian (tercantum dalam informed consent) dan memenuhi kriteria inklusi maupun eksklusi. Kriteria inklusi subyek yaitu berumur 18-30 tahun, memiliki indeks massa tubuh normal antara $18.5-22.9 \mathrm{~kg} / \mathrm{m}^{2}$ dan sehat. Adapun kriteria eksklusi yaitu tidak memiliki riwayat penyakit DM, tidak sedang mengalami gangguan pencernaan, tidak menjalani pengobatan, tidak menggunakan obatobatan terlarang, serta tidak meminum minuman beralkohol.

\section{Pengukuran Indeks Glikemik Sukun Goreng, Sukun Kukus, Sukun Rebus, dan Kukis Sukun}

Penelitian ini dilaksanakan setelah memperoleh izin dari Komisi Etik Penelitian Biomedis Manusia mengenai persetujuan etik (Ethical Approval) No. LB.03.04/KE/4914/2010 tanggal 14 Juni 2010, Badan Penelitian dan Pengembangan Kesehatan Republik Indonesia di Jakarta.

Setiap subyek diminta untuk menjalani pengujian dengan mengkonsumsi 5 jenis perlakuan dalam rentang waktu lima minggu, yaitu sukun goreng (pada minggu pertama), glukosa murni (minggu kedua), sukun kukus (minggu ketiga), sukun rebus (minggu keempat), dan kukis sukun (minggu kelima). Untuk mengetahui Indeks Glikemik masing-masing produk perlakuan, setiap setelah mengonsumsi produk olahan sukun tersebut, dalam rentang waktu dua jam, terhadap subyek dilakukan pengambilan sampel darah.

Prosedur penentuan Indeks Glikemik pangan adalah sebagai berikut (Miller dalam Rimbawan \& Siagian, 2004): a. Pangan uji dan pangan acuan setara dengan 50 gram available carbohydrate diberikan pada subyek penelitian yang telah menjalani puasa penuh (overnight fasting), kecuali air

b. Selama dua jam pasca pemberian (subyek sehat) sampel darah (1-2 $\mu \mathrm{L})$ finger-prick capillary blood samples method berturutturut, diambil pada menit ke-0 (sebelum pemberian), 15, 30, 45, 60, 90, dan 120 setelah pemberian pangan uji

c. Pada waktu yang berlainan (7 hari kemudian/seminggu), hal yang sama dilakukan dengan memberikan pangan acuan, 7 hari berikutnya diberikan pangan uji ke-2, dan 7 hari berikutnya diberikan pangan uji ke-3, serta 7 hari berikutnya diberikan pangan uji ke-4.

d. Kadar glukosa darah (pada setiap waktu pengambilan sampel) ditebarkan pada dua sumbu, yaitu sumbu $x$ (waktu dalam menit) dan sumbu y (kadar glukosa darah)

e. Indeks glikemik ditentukan dengan cara membandingkan luas daerah di bawah kurva (Area Under Curve, AUC) antara pangan yang diukur indeks glikemiknya dengan pangan acuan (glukosa).

\section{Pengolahan dan Analisis Data}

Data hasil analisis kimia dan gelatinisasi kemudian diolah dengan menggunakan Microsoft excel 2007 dan dianalisis secara deskriptif. Data respon glukosa darah diolah untuk mendapatkan nilai indeks glikemik. Pengaruh pengolahan terhadap nilai indeks glikemik dianalisis menggunakan analisis sidik ragam (one way anova) dengan software SPSS 16.0 for windows.

\section{HASIL DAN PEMBAHASAN}

\section{Komposisi Zat Gizi Produk Olahan Sukun}

Menurut Holmes (2005) dan Powell et al. (2002), proses pengolahan akan berpengaruh terhadap komposisi zat gizi produk olahannya. Oleh karena itu, pada penelitian ini dilakukan analisis komposisi zat gizi produk olahan sukun, yaitu antara lain uji proksimat dan total serat pangan. Hasil uji proksimat keempat produk olahan sukun yang menggambarkan pengaruh proses pengolahan terhadap komposisi zat gizi disajikan pada Tabel 1 .

\section{Kadar Air}

Hasil uji proksimat kadar air pada keempat produk olahan sukun menunjukkan bahwa 
sukun rebus memiliki kandungan air tertinggi, yaitu sebesar 79.91 persen. Sukun rebus memiliki kadar air yang tinggi dibandingkan ketiga produk lainnya karena sukun rebus dihasilkan melalui metode perebusan dengan menggunakan media pengantar panas adalah air. Berbeda halnya dengan kukis sukun yang memiliki kandungan air rendah, yaitu 4.24 persen, metode pengolahan yang digunakan untuk menghasilkan kukis sukun adalah melalui proses pemanggangan. Pada proses ini, menggunakan suhu tinggi yang memungkinkan terjadinya proses penguapan air secara berlebihan sehingga produk yang dihasilkan berbentuk sangat padat dan memiliki tekstur keras.

Tabel 1. Hasil Uji Proksimat Produk Olahan Sukun (b/k)

\begin{tabular}{lcccc}
\hline \multicolumn{1}{c}{ Produk Olahan } & $\begin{array}{c}\text { Sukun } \\
\text { Goreng }\end{array}$ & $\begin{array}{c}\text { Sukun } \\
\text { Rebus }\end{array}$ & $\begin{array}{c}\text { Sukun } \\
\text { Kukus }\end{array}$ & $\begin{array}{c}\text { Kukis } \\
\text { Sukun }\end{array}$ \\
\hline Kadar Air (\%) (b/b) & 51.01 & 79.91 & 71.75 & 4.24 \\
Kadar Abu (\%) & 5.35 & 5.30 & 6.98 & 1.98 \\
Kadar Protein (\%) & 1.22 & 3.20 & 2.11 & 3.53 \\
Kadar Lemak (\%) & 20.07 & 0.73 & 0.61 & 30.12 \\
Kadar KH(\%) & 73.36 & 90.78 & 90.30 & 64.37 \\
Kadar serat total (\%) & 8.08 & 6.97 & 7.38 & 4.17 \\
\hline
\end{tabular}

\section{Kadar Protein}

Hasil analisis kandungan protein produk olahan sukun menunjukkan bahwa kukis sukun memiliki kandungan protein tertinggi di antara produk olahan sukun lainnya, yaitu sebesar 3.53 persen. Kandungan protein kukis sukun yang lebih tinggi daripada produk olahan sukun lainnya disebabkan oleh pada proses pengolahan kukis sukun dilakukan penambahan margarin dan susu skim. Sukun goreng memiliki kandungan protein terendah, yaitu sebesar 1.22 persen. Hal ini diduga dikarenakan oleh kerusakan protein pada sukun goreng.

\section{Kadar Lemak}

Hasil analisis lemak empat produk olahan sukun menunjukkan bahwa kukis sukun memiliki kandungan lemak tertinggi, yaitu sebesar 30.12 persen. Hal ini dapat dimaklumi karena pada proses pengolahan kukis sukun ditambahkan margarin sebesar 31.71 persen dari berat adonan per takaran saji. Sukun goreng juga memiliki kandungan lemak yang tinggi $(20.07 \%)$ dikarenakan menggunakan media minyak sawit pada proses penggorengan. Sukun rebus dan sukun kukus tidak terdeteksi karena kadar air kedua produk tersebut cukup tinggi $(0.73 \%$ dan $0.61 \%)$ akibat proses pengolahan dengan metode perebusan dan pengukusan dan tidak adanya penambahan lemak.

\section{Kadar Karbohidrat (by difference)}

Metode analisis kandungan karbohidrat by difference diperoleh melalui penghitungan 100 persen kandungan zat gizi dikurangi penjumlahan hasil analisis abu, protein, dan lemak. Kandungan karbohidrat terbesar pada sukun rebus, yaitu sebesar 90.78 persen. Bahan baku proses pengolahan sukun goreng adalah sukun tanpa penambahan bahan makanan lain di dalamnya. Berbeda halnya dengan kukis sukun yang memiliki kandungan karbohidrat yang lebih rendah dari keempat produk olahan sukun, yaitu sebesar 64.37 persen.

\section{Kadar serat pangan total}

Total serat pangan terdiri atas serat kasar (crude fiber) dan serat makanan (dietary fiber). Hasil analisis total serat pangan menunjukkan bahwa sukun goreng memiliki kadar total serat pangan paling tinggi di antara keempat produk olahan sukun lainnya, yaitu sebesar 8.08 persen. Tingginya kandungan total serat pangan pada sukun goreng akibat proses penggorengan diduga karena terjadinya pembentukan kompleks karbohidrat-lemak yang sulit untuk dicerna dan terhitung sebagai serat pangan (Thornburn et al, 1986). Kandungan total serat pangan yang paling rendah di antara keempat produk olahan sukun adalah kukis sukun $(4.17 \%)$.

\section{Derajat Gelatinisasi Produk Olahan Sukun}

Menurut Wooton et al. (1971) yang dimaksud derajat gelatinisasi adalah rasio antara pati yang tergelatinisasi dengan total pati. Derajat gelatinisasi terbesar pada sukun kukus, yaitu 24.18 persen. Hal ini diduga karena pati yang terkandung dalam sukun kukus telah tergelatinisasi penuh. Selama pemasakan, air, dan panas memperbesar ukuran granula pati. Diduga, sebagian besar pati sukun kukus telah mengembang seluruhnya. Sukun goreng memiliki derajat gelatinisasi yang paling rendah, yaitu sebesar 12.76 persen. Diduga dikarenakan oleh kandungan serat kasar yang lebih tinggi dibandingkan dengan produk olahan sukun lainnya. Kandungan lemak yang relatif tinggi pada sukun goreng dapat menurunkan derajat gelatinisasi. Menurut Harper (1981), lemak akan membungkus butiran pati (kompleks amilosalipid) dan menghambat jumlah air yang dapat diserap oleh pati sehingga nilai derajat gelatinisasi semakin rendah. 


\section{Indeks Glikemik Produk Olahan Sukun}

\section{Penentuan jumlah Pangan Uji dan Acuan}

Pengukuran indeks glikemik pangan dilakukan dengan memberikan pangan uji dengan jumlah setara dengan 50 gram karbohidrat kepada seluruh subyek penelitian. Pangan uji yang diberikan kepada subyek penelitian dilakukan setelah subyek mengalami puasa selama 10 jam sebelumnya (overnight fasting), kecuali air putih. Jumlah produk olahan sukun yang diberikan kepada subyek ditentukan berdasarkan jumlah kandungan available carbohydrate yang menggambarkan kandungan total karbohidrat yang tersedia untuk tubuh sehingga mudah dicerna.

Miller (1990) dan Mendosa (2006) menyatakan jumlah karbohidrat yang digunakan sebagai dasar penentuan jumlah pangan yang diberikan kepada subyek penelitian didasarkan pada pendekatan karbohidrat by difference yang dikurangi dengan jumlah kandungan total serat pangan (karbohidrat available). Jumlah produk olahan sukun (pangan uji) dan acuan yang diberikan kepada subyek penelitian (dalam satuan gram) setara dengan 50 gram available carbohydrate dalam satu kali konsumsi yang disajikan pada Tabel 2 .

Jumlah porsi $(\mathrm{g})=\frac{50 \mathrm{~g} \times 100}{\text { Kadar available carbohydrate }(\% \mathrm{~b} / \mathrm{b})}$

Tabel 2. Jumlah Pangan Uji dan Acuan yang Setara dengan 50 gram Available Carbohydrate $(\mathrm{b} / \mathrm{b})$

\begin{tabular}{lcccc}
\hline Produk Olahan & $\begin{array}{c}\text { KH } \\
(\% \mathrm{~b} / \mathrm{b})\end{array}$ & $\begin{array}{c}\text { Serat } \\
\text { Pangan } \\
\text { Total } \\
(\% \mathrm{~b} / \mathrm{b})\end{array}$ & $\begin{array}{c}\text { Available } \\
\text { Carbohyd- } \\
\text { rate }(\% \mathrm{~b} / \mathrm{b})\end{array}$ & $\begin{array}{c}\text { Jumlah } \\
\text { Pangan } \\
(\mathrm{gram})\end{array}$ \\
\hline Sukun Goreng & 35.94 & 8.08 & 27.85 & 179.53 \\
Sukun Rebus & 18.24 & 6.97 & 11.26 & 443.90 \\
Sukun Kukus & 25.51 & 7.38 & 18.13 & 275.83 \\
Kukis Sukun & 61.64 & 4.17 & 57.46 & 87.01 \\
$\begin{array}{l}\text { Glukosa } \\
\text { monohidrat }\end{array}$ & & & 100.00 & 50.00 \\
\hline
\end{tabular}

\section{Penghitungan nilai indeks glikemik}

Data glukosa darah yang diperoleh dari hasil pengukuran respon glukosa darah subyek penelitian pada masing-masing pangan yang diberikan, kemudian ditebar pada sumbu koordinat dengan sumbu $X$ sebagai waktu (menit) dan sumbu $\mathrm{Y}$ sebagai kadar glukosa darah. Nilai indeks glikemik pangan uji dihitung berdasarkan rumus:

$$
I G=\frac{\text { Luas area di bawah kurva pangan uji }}{\text { Luas area di bawah kurva pangan acuan }} \times 100 \%
$$

Luas daerah di bawah kurva dihitung berdasarkan hasil integral masing-masing persamaan polinom dengan batas 0-120. Nilai Indeks Glikemik masing-masing pangan diperoleh dari rata-rata nilai IG individu subyek (rata-rata dari 6 nilai IG individu).

Menurut Miller (2006) dalam Rimbawan dan Siagian (2004), indeks glikemik glukosa murni ditetapkan 100 dengan glukosa murni sebagai pangan acuan untuk penentuan indeks glikemik pangan lain. Kategori pangan menurut rentang indeks glikemik dengan glukosa murni sebagai pangan acuan, yaitu : IG rendah $(<55)$, IG sedang/intermediate (55-70), dan IG tinggi $(>70)$.

Tabel 3. Nilai Indeks Glikemik Sukun Goreng, Sukun Kukus, Sukun Rebus, dan Kukis Sukun

\begin{tabular}{lc}
\hline \multicolumn{1}{c}{ Produk Olahan } & Indeks Glikemik (IG) \\
\hline Sukun goreng & 82 \\
Sukun kukus & 89 \\
Sukun rebus & 85 \\
Kukis sukun & 80 \\
\hline
\end{tabular}

Hasil pengukuran indeks glikemik menunjukkan bahwa sukun goreng (82), sukun rebus (85), sukun kukus (89), dan kukis sukun (80) memiliki nilai indeks glikemik pangan yang cukup tinggi (>70). Hasil analisis ragam terhadap data nilai indeks glikemik empat pangan uji menunjukkan bahwa pengolahan sukun yang berbeda tidak menunjukkan perbedaan respon glikemik $(\mathrm{P}<0.05)$.

Faktor-faktor yang dapat mempengaruhi nilai indeks pangan, diantaranya adalah cara pengolahan (tingkat gelatinisasi pati dan ukuran partikel), perbandingan amilosa dengan amilopektin, tingkat keasaman dan daya osmotik, kadar serat, kadar lemak dan protein, serta kadar anti gizi pangan (Rimbawan dan Siagian, 2004). Semua produk olahan sukun termasuk ke dalam kriteria pangan dengan indeks glikemik tinggi (>70). Hal ini diduga karena pati sukun merupakan pati berkadar amilosa rendah atau berkadar amilopektin tinggi (Manulang \& Vivin dalam Wincy, 2001). Amilopektin merupakan polimer gula sederhana bercabang, memiliki ukuran molekul lebih besar dan terbuka. Oleh karena itu, amilopektin lebih mudah tergelatinisasi dan akibatnya akan lebih mudah dicerna oleh tubuh. Pangan yang mudah diabsorbsi oleh tubuh dapat menyebabkan respon glukosa darah menjadi lebih tinggi pula. 
Kukis sukun memiliki nilai indeks glikemik yang cukup tinggi (>70). Indeks glikemik yang tinggi pada kukis sukun dapat dimaklumi karena pati sukun termasuk dalam kriteria berkadar amilosa rendah atau dengan kata lain berkadar amilopektin tinggi. Oleh karena itu, diduga menyebabkan komponen karbohidrat pa da kukis sukun lebih mudah dicerna dan diserap oleh tubuh. Proses pencernaan dan penyerapan karbohidrat inilah yang dapat menyebabkan respon glikemik pada kukis sukun menjadi tinggi. Dibandingkan dengan produk olahan sukun lainnya (sukun goreng, sukun kukus, dan sukun rebus) nilai indeks glikemik kukis sukun paling rendah. Hal ini diduga oleh kandungan lemak $(30.12 \%)$ dan protein $(3.53 \%)$ paling tinggi dibandingkan dengan produk olahan sukun lainnya. Penggunaan margarin, kuning telur, dan susu skim pada kukis sukun yang menyebabkan kandungan lemak dan protein kukis sukun menjadi paling tinggi di antara produk olahan sukun lainnya. Kadar lemak yang cukup tinggi pada kukis sukun dapat menurunkkan nilai indeks glikemik karena lemak tersebut cenderung dapat memperlambat laju pengosongan lambung. Oleh karena itu, tidaklah heran jika kukis sukun yang memiliki kandungan lemak tinggi dibandingkan produk olahan lainnya memiliki indeks glikemik yang lebih rendah daripada pangan sejenis berkadar lemak rendah (Rimbawan dan Siagian, 2004).

Indeks glikemik yang tinggi pada sukun goreng (82 \%) diduga disebabkan oleh ukuran butiran pati sukun goreng. Menurut Rimbawan dan Siagian (2004), ukuran pati mempengaruhi proses gelatinisasi. Ukuran partikel berkaitan dengan luas penampang permukaan total. Semakin kecil ukuran partikel, semakin besar luas permukaan total pangan. Menurut Snow dan O'Dea (1981), ukuran butiran pati yang makin kecil mengakibatkan mudah terdegradasi oleh enzim. Hal ini menyebabkan enzim mudah bekerja. Semakin mudah enzim bekerja, maka semakin cepat pencernaan dan penyerapan karbohidrat pati. Kadar lemak yang terkandung pada sukun goreng pun cukup tinggi (20.07\%) dan menempati posisi kedua setelah kukis sukun. Oleh karena itu, tidaklah heran jika sukun goreng yang memiliki kandungan lemak tinggi kedua dibandingkan produk olahan lainnya memiliki indeks glikemik kedua yang lebih rendah daripada pangan sejenis berkadar lemak rendah.

Sukun rebus dan sukun kukus memiliki nilai indeks glikemik yang tinggi $(>70)$. Hal ini diduga pada proses pengolahan sukun rebus menggunakan air dalam jumlah yang besar (perebusan) sehingga menyebabkan terjadinya proses gelatinisasi secara lebih cepat. Sukun kukus mengalami proses pemasakan, air, dan panas yang dapat memperbesar ukuran granula pati. Beberapa granula terpisah dari molekul pati. Apabila sebagian besar granula pati telah mengembang, maka pati tersebut dinyatakan tergelatinisasi penuh. Menurut Rimbawan dan Siagian (2004), granula yang mengembang dan molekul pati bebas ini sangat mudah dicerna karena enzim pencerna pati di dalam usus halus mendapatkan permukaan yang lebih luas untuk kontak dengan enzim. Reaksi cepat dari enzim ini menghasilkan peningkatan kadar gula darah yang cepat. Oleh karena itu, sukun kukus yang mengandung pati tergelatinisasi penuh memiliki indeks glikemik yang tinggi. Menurut Thornburn et al (1986), indeks glikemik yang meningkat disebabkan karena daya kelarutan dan kecernaan pati juga meningkat karena proses gelatinisasi yang cepat.

Penelitian mengenai indeks glikemik produk olahan sukun masih sangat terbatas. Hasil penelitian Bahado et all (2006) dan Ramdath et al (2004) menunjukkan bahwa nilai indeks glikemik sukun rebus adalah 60 yang termasuk dalam kategori pangan dengan kadar indeks glikemik sedang. Hal ini berbeda dengan hasil penelitian yang didapatkan peneliti. Indeks glikemik sukun rebus 85 yang termasuk dalam kategori indeks glikemik pangan tinggi. $\mathrm{Hal}$ ini diduga karena proses pengolahan dan varietas sukun yang digunakan sebagai sampel penelitian berbeda. Menurut Hariss dan Karmas (1974), varietas tanaman yang berbeda dapat menyebabkan susunan zat gizi yang berbeda pula. Keragaman ini diakibatkan oleh banyaknya faktor yang saling terkait, terutama faktor genetik, sinar matahari, curah hujan, topografi, tanah, lokasi, musim, pemupukan, dan derajat kemasakan. Susunan hasil tanaman pangan dari galur yang sama tetapi tumbuh pada tempat yang berbeda, sering berbeda pula. Hasil penelitian Marsono (2001) bahwa nilai glikemik sukun kukus adalah 90 yang termasuk pada kategori pangan dengan indeks glikemik yang tinggi. Penelitian ini menguatkan hasil penelitian bahwa indeks glikemik sukun kukus tinggi (89). Penelitian Marsono (2001) menunjukkan bahwa indeks glikemik produk olahan sukun kukus tinggi, yaitu 90. Penelitian tersebut memperkuat hasil penelitian ini. Informasi mengenai nilai indeks glikemik produk olahan sukun dapat dilihat pada Tabel 4. 
Tabel 4. Nilai Indeks Glikemik Produk Olahan Sukun dari Beberapa Penelitian

\begin{tabular}{lclcc}
\hline \multicolumn{1}{c}{ Peneliti } & Produk Olahan Sukun & Prosedur Pengolahan Sukun & $\begin{array}{c}\text { Nilai Indeks } \\
\text { Glikemik }\end{array}$ & Tahun \\
\hline Marsono & Sukun kukus & Tidak dijelaskan & 90 & 2001 \\
Ramdath et all & Sukun rebus & $\begin{array}{l}\text { Direbus 26 menit, dibekukan, } \\
\text { dipanaskan kembali selama1 menit. }\end{array}$ & 60 & 2004 \\
Bahado et all & Sukun rebus & Direbus 26 menit & 60 & 2006 \\
\hline
\end{tabular}

\section{KESIMPULAN}

Berbagai jenis pengolahan pangan menghasilkan komposisi zat gizi yang berbeda pada produk olahan sukun (Artocapus altilis). Perbedaan komposisi zat gizi produk olahan ini disebabkan oleh penggunaan komposisi zat yang ditambahkan berbeda (seperti margarin, minyak sawit, telur, dan lain-lain), dan proses pengolahan yang berbeda (menggoreng, mengukus, merebus, dan memanggang).

Hasil pengukuran indeks glikemik menunjukkan bahwa tiap produk olahan sukun dengan proses pengolahan yang berbeda memiliki respon glikemik yang berbeda pula walaupun berada dalam satu kategori yang sama. Produk olahan kukis sukun (80), sukun goreng (82), sukun rebus (85), dan sukun kukus (89) berada pada kategori pangan dengan nilai indeks glikemik yang tinggi (>70). Diduga dikarenakan pati sukun termasuk ke dalam pati berkadar amilopektin tinggi. Hasil analisis ragam terhadap data nilai indeks glikemik empat produk olahan sukun menunjukkan bahwa pengolahan sukun yang berbeda tidak menunjukkan perbedaan respon glikemik yang berbeda $(P<0.05)$.

Nilai indeks glikemik sukun goreng, sukun kukus, sukun rebus, dan kukis sukun termasuk ke dalam kategori indeks glikemik tinggi, sehingga tidak direkomendasikan untuk diabetesi. Oleh karena itu, untuk menurunkan nilai indeks glikemik produk olahan sukun, salah satu caranya adalah dengan penambahan lemak dan protein. Akan tetapi, hal ini harus dilakukan secara bijaksana dan membutuhkan penelitian ilmiah lebih lanjut. Masih banyak berbagai jenis produk olahan sukun lainnya yang sering dikonsumsi oleh masyarakat, sehingga penelitian mengenai nilai indeks glikemik berbagai produk olahan sukun dapat dikembangkan lebih lanjut.

\section{DAFTAR PUSTAKA}

Bahado PS, Wheatley AO, Ahmad MH, Morrison EY, \& Asemota HN. 2006. Food Processing Methods Influence the Glycaemic
Indices of Some Commonly Eaten West Indian Carbohydrate-Rich Foods. $\mathrm{Br} \mathrm{J}$ Nutr, 96, 476-481.

Harris RS \& Karmas E, editor. 1989. Nutritional Evaluation of Food Processing (Achmadi $\mathrm{S}$, penerjemah). Penerbit ITB, Bandung.

Holmes B. 2005. The Glycemic Index vs Mom's Homemade Chicken and Noodles. Thought Bullets, University of Wyoming.

Koswara S. 2006. Sukun sebagai Cadangan Pangan Alternatif. [terhubung berkala]. http://www.ebookpangan.com [20 September 2010].

Marsono Y, Wiyono P, dan Noor Z. 2002. Indeks Glikemik Kacang-kacangan [abstrak]. Jurnal Teknologi dan Industri Pangan. XIII, 211-216.

Mendosa. 2006. The Glycemic Index. [terhubung berkala]. www.mendosa.com/gi. htm. [20 Juli 2010]

Miller JCB, Colagiuri S, Crossman S, Allen A, Roberts DC, \& Truswell AS. 1990. LowGlycemic Index Foods Improve LongTerm Glycemic Control in NIDDM. Diabetes Care, 14, 95-101.

Powell KF, SHA Holt, \& JCB Miller. 2002. International Table of Glycemic Index and Glycemic Load Values. Am J Clin Nutr 76(1):5-56.

Ramdath DD, Isaacs RLC, Teelucksingh S, \& Wolever TMS. 2004. Glycaemic Index of Selected Staples Commonly Eaten in the Carribean and the Effects of Boiling v.Crushing. Br J Nutr 91, 971-977.

Rimbawan \& Siagian A. 2004. Indeks Glikemik Pangan, Cara Mudah Memilih Pangan yang Menyehatkan. Penebar Swadaya, Jakarta.

Saptoning. 2010. Manfaat Sukun Sebagai Sumber Pangan Alternatif. [terhubung ber- 
kala]. http://www2.bbpp-lembang.info/ index.html. [9 April 2010].

Thornburn AW, Brand JC, \& Truswell AS. 1986. The Glycemic Index of Food. The Medical Journal of Australia 144, 580-582.

Widowati S. 2010. Pangan Sukun (Artocarpus communis) Sebagai Pangan Sumber Karbohidrat dalam Mendukung Diversifikasi
Konsumsi Pangan. [terhubung berkala]. www.majalahpangan.com. [13 Oktober 2010].

Wincy. 2001. Karakteristik Tepung Sukun Pramasak Hasil Pengeringan Kabinet dan Aplikasinya untuk Substistusi Tepung Terigu pada Pembuatan Kukis. Skripsi Sarjana, Fakultas Teknologi Pertanian, IPB, Bogor. 